\title{
WHATSAPP MEDIA IN ONLINE LEARNING DURING COVID-19 PANDEMIC
}

\author{
Dewi suriyani Djamdjuri ${ }^{1}$ and Atiyatul Kamilah ${ }^{2}$ \\ English Education Program Faculty of Teacher Training and Education \\ Universitas Ibn Khaldun Bogor ${ }^{1}$ \\ dewi.suriyani@uika-bogor.ac.id ${ }^{1}$; atiyatulkamilah36@gmail.com ${ }^{2}$
}

\begin{abstract}
Since early of 2020 the world has been hit by a virus called the corona virus which was originated from the city of Wuhan, China. Corona virus is a microorganism that causes respiratory problems starting from mild to severe symptoms, the incubation or quarantine period is between 6 to 14 days. All activities are stopped, one of which is the Educational Institution. Schools cannot be implemented face-to-face, but schools must continue to run. Therefore, the Minister of Education and Culture of the Republic of Indonesia through Permendikbud No. 4 of 2020 provides a policy on a series of learning in an emergency situation of the spread of Covid-19, namely distance learning (PJJ) or online learning. Online learning using WhatsApp or the Learning Management System (LMS) media are almost used by teachers and students. This study uses a qualitative method to determine which platforms / media are easily accessible for online learning. The result shows that WhatsApp media is very easy to use in online learning during the pandemic-19. There is $75 \%$ of the respondents use WhatsApp as learning media and only $25 \%$ use LMS. In otherwise, some teachers also stated that online learning felt less effective because of internet signals and data.
\end{abstract}

Keywords: Online Learning, WhatsApp, Covid-19

\section{INTRODUCTION}

Education has a very important role in the progress of a nation. Education is one of effective ways of preparing good generation for better future (Djamdjuri, The Effectiveness of Character Education in English Language Teaching Through the Islamic Teaching Materials, 2016). The Government of the Republic of Indonesia in developing education in Indonesia adheres to one of the goals of the Indonesian nation as stated in the preamble to the fourth paragraph of the 1945 Constitution, namely to educate the nation's life. This national education system is manifested in Law No. 20 of 2003 concerning the National Education System. The national education system is an integrated whole component of education to achieve the goals of national education (Budi, 2012).

In early 2020 starting at the end of January, the world was hit by a virus called the corona virus which originated from the city of Wuhan, China. The corona virus causes all face-to-face (inperson) activities to stop. According to (Dewi, 2020), Corona virus is a microorganism that causes respiratory problems starting from mild to severe symptoms, the incubation or quarantine period is between 6 to 14 days. The spread of the corona virus is very easy and very fast because it can be through direct contact with other infected humans, therefore all activities involving associations with many people are stopped and transferred to WFH or working from home to prevent the spread and spread of Covid-19. Although school education cannot be carried out face-toface, schools must continue to run. Therefore, the Minister of Education and Culture of the Republic of Indonesia through Permendikbud No. 4 of 2020 provides a policy on a series of lessons learned in an emergency situation of the spread of Covid-19. 
Based on the provisions of the Ministry of Education, teaching and learning activities are carried out or transferred to online schools or PJJ (distance learning), therefore learning must continue and be active as usual even though through distance learning or online learning. According to (Syarifudin, 2020), active learning is learning that is carried out optimally and is supported by an adequate medium, method of tools, and materials. In this era, technology is very rapidly developing; there are many kinds of media, tools and materials in digital form. Due to pandemic outbreak, learning is conducted in virtual form. Virtual learning or distance learning (PJJ) or online learning is not a problem because learning activities are not limited by space and time, especially with the current situation which is supported by rapidly developing technological advances, learning can be done with an online system, and learning activities can takes place at home, at school, and in the community (Dewi, 2020). Through the use of technology as learning media, it makes students more enjoy and easy to learn (Djamdjuri \& Kirana , 2020). Based on the background describing above, the researchers conducted a research entitled "WhatsApp media for online learning during the Covid-19 pandemic".

\section{LITERATURE REVIEW}

During the COVID-19 crisis, the emergence of COVID-19 was arguably a much-anticipated event. According to (Kirlin, 2020) reported the novel coronavirus disease (COVID-19) quickly spread worldwide, with more than 420,000 dead cases caused of the virus outbreak by early June 2020. Although COVID-19 was known to have spread widely in the weeks following the outbreak, insufficient data from China hindered understanding and response. Patients have problems with emotional management and behavioral control, resulting in difficulties in following universal infection control guidelines, such as maintaining physical distance, hand hygiene, or wearing surgical masks. When the people do not rule out the possibility at a workplace and educational institution, the transmission of the COVID-19 might occur high.

\section{Distance Learning}

Distance learning (PJJ) is a learning activity that uses technology, where students complete a task and make decisions at any time (Gunawan, 2020). According to (Bower, 2015), the purpose of distance learning (PPJ) or online learning is to maximize a decision made by online students by being given the correct knowledge and getting additional information that can be accessed at any time. A most prominent characteristic of a distance learning (PJJ) or online learning is providing an easy and flexible way for teachers and students to determine online learning schedules without specifying a space or location.

In the online learning process, various platforms can be used in online learning such as the learning management system (LMS), WhatsApp, Google Class, the Zoom application or YouTube YouTube. Various platforms that are already available can help smoothing the learning process (Gunawan, 2020). According to Roida Pakpahan and Yuni Fitriani in their research entitled "Analysis of the Use of Information Technology in Distance Learning amid the Corona Covid-19 Virus Pandemic" that technology really helps the learning process online or online during the Covid-19 virus outbreak. This technology makes all learning processes run smoothly and well ( Pakpahan \& Fitriani, 2020).

The application of learning methods must be in accordance with the learning subjects and abilities of students, therefore the way to overcome 
problems is to apply online or online learning, namely using internet or android applications. In the world of education, teachers must master the HOTS (higher order of thinking skills) learning method in the 2013 curriculum guidance. The assessment of the learning outcomes is expected to help students add critical thinking skills (HOTS) if students can think critically or think at a high level, it will also encourage to think broadly and deepen the material being studied (Fanani, 2018). Through online teaching and learning activities with students, teachers must still be able to provide relevant material that has been scheduled by the school.

\section{WhatsApp}

According to (Amry, 2014) WhatsApp media is an application that is often used and effective for distance learning or online learning during the pandemic. Teachers and students are already accustomed to using this application in their daily teaching and learning process. In a study conducted by (Amry, 2014), namely The impact of WhatsApp mobile social learning on the achievement and attitudes of female students compared with face to face learning in the classroom, that the benefits of the WhatsApp application in the process of teaching and learning activities have a positive impact because students are more happy when learning to use innovative applications such as using gadgets, so that students have positive results in students' learning achievement.

WhatsApp is software designed to share easy-to-use text, voice notes, and images (Suryani, 2017). Since WhatsApp receives fees from using internet data, the cost of using WhatsApp is very cheap. WhatsApp is also the medium that is commonly used today by all as opposed to other networking apps such as Instagram, sms, e-mail and others.

\section{METHOD}

This research uses a qualitative approach. Qualitative research is the natural collection of data (Gay, Mills, \& Airasian, 2006). Researchers use interview as the technique of collecting the data. The interview was conducted via goggle form. Interview is a technique of collecting data through question and answer conducted by researchers and respondents. During the Covid-19 pandemic, interviews were conducted online using the goggle form by educators at BMS Bogor High School.

Results and Discussion

Based on the provisions of the Ministry of Education. Teaching and learning activities are carried out or transferred to online schools or PJJ (distance learning) which are implemented by SMK BOGOR MUHIDDIN SCHOOL (BMS) which utilizes various kinds of technology media so that teaching and learning is carried out properly and smoothly. The researcher of this writing aims to determine the extent to which a whatsapp media is very useful in distance learning (PJJ) or online learning.

\section{RESULTS AND DISCUSSION}

Based on the provisions of the Ministry of Education, teaching and learning activities are carried out or transferred to online schools or PJJ (distance learning) which are implemented by SMK BOGOR MUHIDDIN SCHOOL (BMS) which utilizes various kinds of technology as learning media so that teaching and learning is carried out properly and smoothly. The researcher of this writing aims to determine the extent to which a WhatsApp media is very useful in distance learning (PJJ) or online learning. From the interview result as shown in Figure 1, there is $75 \%$ of the respondents use WhatsApp as learning media and only $25 \%$ use LMS. 


\section{Hasil wawancara online}

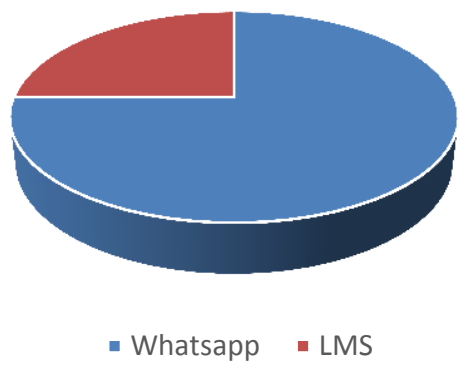

Figure 1 Online media used in SMK BMS during the Covid-19 pandemic.

Moreover, the results obtained from interviews using the goggle form show that during the Covid -19 pandemic it was easier for teachers to implement teaching and learning using WhatsApp media compared with the use of learning management system (LMS). This is because WhatsApp is more efficient because all students have and understand in using this application. How to use WhatsApp is done by the teacher, namely giving an assignment and direction through the WhatsApp group to students. This is in accordance with (Suryani, 2017) stated that WhatsApp is software designed to send text, voice notes, and images that are easy to use. The cost of using WhatsApp is very cheap because WhatsApp collects fees from using internet data. When compared to other communication applications such as Instagram, sms, e-mail and others, WhatsApp is still the medium that is widely used today by everyone.

According to the results of the interview using the goggle form shows that WhatsApp media has advantages and disadvantages in teaching and learning activities. Table 1 below shows some of the advantages and disadvantages of WhatsApp media from the interview given to some teachers.

Tabel 1. Results of Online Interviews

\begin{tabular}{|l|l|}
\hline \multicolumn{1}{|c|}{ ADVANTAGES } & \multicolumn{1}{|c|}{ DISADVANTAGES } \\
\hline $\begin{array}{l}\text { Membantu proses pembelajaran, dan membantu } \\
\text { siswa yang tidak mengerti LMS }\end{array}$ & $\begin{array}{l}\text { Apabila jaringan signal jelek, akan } \\
\text { menghambat proses pngiriman bahan } \\
\text { ajar }\end{array}$ \\
$\begin{array}{l}\text { Helping the learning process, and helping students } \\
\text { who do not understand LMS. }\end{array}$ & $\begin{array}{l}\text { If the signal network is bad, it will hinder } \\
\text { the process of sending teaching materials }\end{array}$ \\
\hline $\begin{array}{l}\text { Lebih efesien karna hampir semua siswa punya } \\
\text { dan paham dalam penggunaan media sosial ini }\end{array}$ & $\begin{array}{l}\text { Dalam pertemuan vidio confren sangat } \\
\text { terbatas }\end{array}$ \\
$\begin{array}{l}\text { It is more efficient because almost all students have } \\
\text { and understand the use of social media }\end{array}$ & $\begin{array}{l}\text { In video conference the meetings is very } \\
\text { limited }\end{array}$ \\
\hline $\begin{array}{l}\text { Lebih mudah di fahami oleh guru atau siswa dan } \\
\text { tidak memakan data kouta yang banyak }\end{array}$ & $\begin{array}{l}\text { Terkadang agak lambat respon ketika } \\
\text { banyak pesan yang masuk }\end{array}$ \\
$\begin{array}{l}\text { It is easier for the teacher or student to understand } \\
\text { and does not take up a lot of quota data. }\end{array}$ & $\begin{array}{l}\text { Sometimes the response is a bit slow when } \\
\text { there are many incoming messages }\end{array}$ \\
\hline
\end{tabular}

Table 1 shows that WhatsApp is very easy to access by everyone including students. This makes it easier for teachers to provide material to students during the Covid-19 pandemic and students do not find it difficult in the learning process. It is in line with (Amry, 2014) which stated that WhatsApp is a 
media easy to use especially in pandemic era.

\section{CONCLUSION}

The application of social distancing to avoid the covid-19 virus makes learning activities online or distance learning (PJJ), but, learning must remain active and run smoothly. The results found that in SMK BMS implement several applications or platforms such as WhatsApp and learning management system (LMS) for the teaching and learning process. Some of the students are using WhatsApp and some are using the Learning Management System (LMS), but more educators are using the WhatsApp platform or media in the teaching and learning process during the Covid-19 pandemic. Problems that often arise in online activities or online learning are internet data packages or limited internet signals by teachers and students.

\section{REFERENCES}

Amry, A. B. (2014). The impact of Whatsapp mobile social learning on the achievement and attitudes of.

Bower, M. D. (2015). Design and implementation factors in blended synchronous

learningenvironments: Outcomes from a cross-case analysis. Computers \& Education, 86, 1-17.

Budi, S. R. (2012). Evaluasi Trend Kualitas Pendidikan di Indonesia. Jurnal Penelitian dan Evaluasi Pendidikan, 511-532.

Dewi, W. A. (2020). Dampak Covid-19 Terhadap Implementasi Pembelajaran Daring Di Sekolah Dasar. Jurnal Ilmu Pendidikan 2(1).

Djamdjuri, D. S. (2016). The Effectiveness of Character Education in English Language Teaching Through the Islamic Teaching Materials. Bogor:
Pascasarjana Universitas Ibn Khaldun.

Djamdjuri, D. S., \& Kirana , G. C. (2020). Memperkenalkan cara pengaplikasian komputer terhadap anak sekolah dasar (Ciampe udik,caringin jangkung). ABDI DOSEN , jurnal pengabdian pada masyarakat, 146-151.

Fanani, M. Z. (2018). Strategi Pengembangan Soal Hots Pada Kurikulum 2013. Edudeena Journal of Islamic Religious Education.

Gay, L. R., Mills, G. E., \& Airasian, P. (2006). Educational Research Competency for Analysis andApplications, Eight Edition. Singapore: Pearson Prentice Hall.

Gunawan, N. M. (2020). Variations of Models and Learning Platforms for Prospective Teachers During the COVID-19 Pandemic Period. indonesian Journal of Teacher Education Vol. 1 No. 2, 61-70.

Kirlin, J. (2020). COVID-19 Upends Pandemic Plan. American Review of Public Administration, 50(6-7). https://doi.org/10.1177/02750740 20941668, 467-479.

Pakpahan, R., \& Fitriani, Y. (2020). Analisa Pemanfaatan Teknologi Informasi Dalam Pembelajaran Jarak Jauh Di Tengah Pandemi Virus Corona Covid-19. Journal of Information System Applied Management and Accounting Research 4(2).

Suryani, R. (2017). Fungsi Whatsapp Grup Shalehah Cabang Bandar Lampung sebagai Pengembangan Media Dakwah dalam Membentuk Akhlakul Kharimah, (Lampung ).

Syarifudin, A. S. (2020). Impelementasi Pembelajaran Daring Untuk Meningkatkan Mutu Pendidikan sebagai Dampak Diterapkannya 
Whatsapp Media in Online Learning during Covid-19 Pandemic

(Dewi suriyani Djamdjuri\& Atiyatul Kamilah)

Social Distancing. Metalingua

Jurnal Pendidikan Bahasa dan

Sastra Indonesia, 31-33. 